\title{
CAUSAS DE AFASTAMENTO DO SERVIÇO POR ACIDENTE DE TRABALHO EM UM HOSPITAL GERAL
}

\author{
Vanda Elisa Felli da Silva*
}

\section{NOTA PRÉVIA}

SILVA, V.E.F. da Causas de afastamento do serviço por acidente de trabalho em um hospital geral. Nota prévia. Rev. Esc. Enf. USP, São Paulo, 19(2):187-188, 1985.

O presente estudo identifica e analisa os acidentes de trabalho ocorridos em um hospital geral, levando em consideração características pessoais do acidentado, relativas ao serviço, e do acidente propriamente dito

As atividades inerentes às organizações hospitalares, são desenvolvidas por uma grande diversificação de mão de obra, pessoal lotado em diferentes áreas como serviços técnicos, gerais, etc. Os riscos de acidente de trabalho, a que estão sujeitos os individuos que militam nessas áreas, assemelham-se, em grande parte, àqueles a que estão sujeitos os indivíduos que trabalham em indústrias.

Embora existam poucos levantamentos estatísticos publicados sobre a incidência de acidentes de trabalho entre o pessoal hospitalar, acredita-se, pela observação não sistematizada, que é grande o número de afastamentos por acidente nessas instituiçōes. Esse fato é relevante, uma vez que o hospital tem por finalidade a promoção, proteção e recuperação da saúde dos individuos.

O objetivo do estudo é subsidiar, pelos resultados, futuros programas de desenvolvimento de pessoal, na área hospitalar.

São levadas em consideração algumas características como: sexo e idade mais freqüentes dos acidentados, áreas de serviço onde os acidentes ocorrem, funções executadas pelos funcionários, causa de afastamento pelo acidente de trabalho, tipo de acidentes e meses em que ocorrem.

O instrumento da coleta de dados utilizado é um formulário e os dados colhidos representam $100 \%$ dos acidentes de trabalho ocorridos no período determinado para a coleta de dados.

O estudo encontra-se, atualmente, na fase de tabulação de dados.

- Enfermeira. Auxiliar de Ensino do Departamento de Orientaçáo Profissional da Escola de Enfermagem da USP - disciplina Adminintracão aplleada a Finformagem. 
SILVA, V.E.F. da Causes of removal from professional duty due to accident of work in a general hospital. Preliminary note. Rev. Esc. Enf. USP, São Paulo, 19(2): 187-188, 1985.

This study identifies and analyses the accidents of work that took place in a general hospital, taking into consideration the personal characteristics of the injured, characteristics regarding the job and also of the accident itself.

The activities inherent to hospital organizations are accomplished by a great diversification of workers, distributed through different areas, such as technical services, general services, etc. The risks of an accident of work to which are exposed the individuals that work in these areas, are similar, in many ways, to those which can occur to individuals who work in industries.

Although there are few published statistical data about the occurence of accidents of work among hospital workers, mon sistematic observation, has that shown the number of removals by accident in those institutions is significant. This is a relevant fact, since the purpose of the hospital is the promotion, protection and recovery of the individual's health.

The objective of the study is to assist, by the results obtaned, future programs of personnel development in similar hospital.

Some characteristics are taken into consideration such as the sex and age of persons suffering accidents, areas of service where the accidents occur, duties performed by workers, cause of absence by of work, type of accidents and the months of the years when they occur.

The instrument used for the collection of data is a formulary. The data obtained represent $100 \%$ of the accidents of work that have occured during the period of data.

The colected data are at present being analysed. 